\title{
Forum on Nancy Krieger's geospatial approach to social epidemiology: an introduction
}

\author{
Daniel Sui · James Holt
}

Published online: 14 February 2009

(C) Springer Science+Business Media B.V. 2009

Understanding the social determinants of health remains a global priority (WHO 2008). Advances in social epidemiology during the past 20 years have revealed a complex web of social factors that explain the distribution of mortality and morbidity at multiple scales. Among the numerous ground-breaking works published in social epidemiology, Nancy Krieger's discoveries stand out prominently for geographers due to her overt emphasis on spatial/geographical dimension of her work. The five papers in this Forum focus on Nancy Krieger's geospatial approach to social epidemiology and how her work has helped us understand crucial health issues from a geographical perspective. Hailed as the people's epidemiologist (Drexler 2008), Nancy Krieger's contributions to epidemiology in general and social epidemiology in particular are multi-faceted. This Forum only covers Krieger's work related to the geospatial themes. Readers interested in Nancy Krieger's other works are referred to her web site (http://www.hsph.harvard. edu/faculty/nancy-krieger/).

We would like to thank all the contributors to this Forum who delivered their papers on time. Thanks

D. Sui $(\bowtie)$

Department of Geography, Texas A \& M University,

College Station, TX 77845-3147, USA

e-mail: geojournaleditor@yahoo.com

J. Holt

Center for Disease Control, Atlanta, USA are also due to Nancy Krieger who completed her rejoinder in a timely fashion. Hopefully, this Forum starts an interesting dialogue between geographers and epidemiologists. The complex connections between social justice and public health, between our bodily truths and the bodily politic mandate an interdisciplinary approach. It is our goal that this Forum will reach an interdisciplinary audience in epidemiology, public health, geography, planning, and other branches of social sciences so that we can keep the conversation going for this very important topic.

\section{References}

Drexler, M. (2008). People's epidemiologist. Harvard Magazine. March-April, 25-33. Available on-line at: http:// harvardmagazine.com/2006/03/the-peoples-epidemiologi. html. Accessed on 31 Dec 2008.

WHO (2008). Closing the gap in a generation: Health equity through action on the social determinants of health. Final report of the Commission on Social Determinants of Health. Geneva: Available at: www.who.int/social_determinants/ final_report/en/index.html. Accessed 4 Jan 2008. 